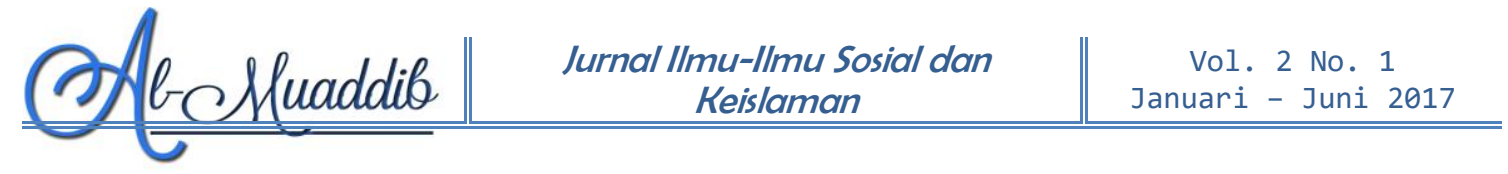

\title{
MANAJEMEN KEPALA SEKOLAH DALAM MENINGKATKAN MUTU PENDIDIKAN DI SMP MUHAMMADIYAH 29 PADANGSIDIMPUAN
}

\author{
Oleh: \\ Darliana Sormin, MA \\ Dosen Fakultas Agama Islam Universitas Muhammadiyah Tapanuli \\ Selatan \\ Email: anamuthmainnah82@gmail.com
}

\begin{abstract}
This study discusses the principal's management in improving the quality of education in midle school Muhammadiyah 29 Padangsidimpuan. The purpose of this study is to find out how the planning and implementation of school principals in improving the quality of education in midle school Muhammadiyah 29 Padangsidimpuan. The type of this research is qualitative descriptive by using interview, observation, and documentation as data collection. Analyze data by compiling data, managing data, then describing it systematically. The result of the principal's management in improving the quality of education at midle school Muhammadiyah 29 Padangsidimpuan is the principal conducting meetings to plan the annual program, then the results of the meeting will be socialized to teachers, students, parents and school committees, then in improving the quality of principals' Activities such as: pengajian, muhadarah by presenting ustadz, practice of prayer, then familiarize the students to be close to the Qur'an by doing activities one day one verse of a verse done in rotation and in reading every morning apple. Then in the process of learning the principal suggests that teachers use varied methods, discipline of the class entry schedule, the existence of job accountability, deliberation in deciding a problem, openness in terms of costing fees and development money.
\end{abstract}

\section{Keywords: Management, Headmaster, Quality of Education}

\section{A. Pendahuluan}

Sekolah merupakan lembaga pendidikan yang berfungsi sebagai "agen of change (agen perubahan)", bertugas untuk membangun peserta didik agar sanggup memecahkan masalah nasional (internal) dan menenangkan persaingan internasional (eksternal). Kepemimpinan pendidikan yang efektif memberikan dasar dan menempatkan tujuan pada posisi penting untuk merubah norma-norma dalam program 


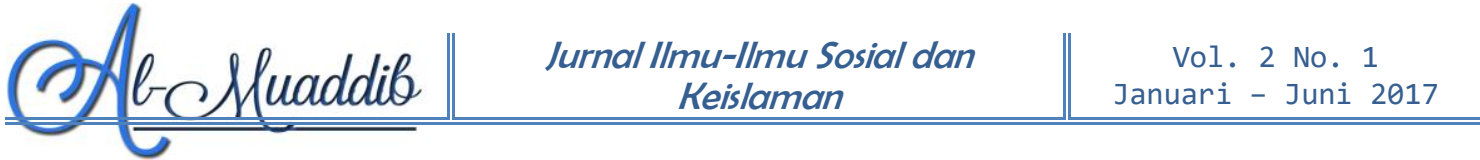

pembelajaran, meningkatkan produktifitas, dan mengembangkan pendekatan-pendekatan yang kreatif untuk mencapai hasil yang maksimal dan program institusi pendidikan. ${ }^{1}$

Kekuasaan kepala sekolah tergantung pada pelaksanaan manajemen berbasis sekolah. Kepala sekolah harus menjadi learning person seseorang yang senantiasa menambah pengetahuan dan keterampilannya. Perhatian kepala sekolah meliputi keseluruhan lingkungan fisik sekolah, kegiatan dan interaksi fungsionalnya mulai dari gedung sampai sudut-sudut halamannya, kantor, ruang belajar, lapangan parkir, dan sebagainya. ${ }^{2}$

Berhasil atau tidaknya suatu lembaga pendidikan tergantung dari bagaimana cara seorang kepala sekolah dalam menjalankan kepemimpinannya dan guru tidak akan terarah tanpa adanya supervisi dari kepala sekolah. Kepala sekolah yang berhasil adalah kepala sekolah yang mampu memahami keberadaan sekolah sebagai organisasi yang kompleks dan unik serta mampu melaksanakan peranannya sebagai seorang yang diberi tanggung jawab untuk memimpin sekolah. Kepala sekolah memiliki peran yang sangat menentukan untuk maju mundurnya sebuah lembaga penidikan.

Pendidikan sebagai sarana vital dalam pengembangan Sumber Daya Manusia merupakan suatu kebutuhan yang tidak dapat dipisahkan dari kehidupan manusia dalam mencerdaskan kehidupan bangsa dan membentuk manusia terampil di bidangnya. Upaya dalam meningkatkan kualitas pendidikan terus-menerus dilakukan baik secara konvensional maupun secara inovatif. Sekolah yang dikelola dengan baik, dari segi pembelajaran, sumber daya manusia dalam hal ini pendidik serta manajemennya maka sekolah akan menghasilkan output (siswa) yang berkualitas yang mampu bersaing ditempat yang lebih besar tantangnya dan lebih kompleks. Sedangkan sekolah yang

${ }^{1}$ Syaiful Sagala, Administrasi Pendidikan Kontemporer (Bandung: Alfabeta 2008), hlm.172.

IIbid, hlm. 173. 
manajemennya kurang baik tidak akan memberikan kualitas dan lulusan yang baik. Banyak sekolah yang tidak terkelola dari segi sistem pembelajaran dan manajemennya sehingga sekolah tersebut tidak maju dan tidak mampu bersaing dalam industri pendidikan saaat ini.

Pendidikan bukan sekedar upaya untuk memberikan pengetahuan yang berorientasi pada target penguasaan materi (peserta didik lebih banyak menghafal dari pada memahami materi) yang diberikan pendidik. Akan tetapi hendaknya pendidik juga memberikan sebuah pedoman hidup (pesan pembelajaran) kepada peserta didik yang akan bermanfaat bagi dirinya dan manusia lain.

Pendidikan juga harus memberikan hiburan kepada peserta didik agar bisa menjalankan aktivitas pembelajaran dengan menyenangkan bukan karena keterpaksaan. Pernyataan tersebut diperkuat oleh pendapat Ahmad Sabri dalam bukunya bahwa orang yang sudah melakukan proses pembelajaran diharapkan akan dapat merasa lebih bahagia, memanfaatkan alam sekitar, menjaga kesehatan, meningkatkan pengabdian untuk keterampilan serta melakukan pembedaan (terdapat perbedaan keadaan antara sebelum dan sesudah melakukan proses pembelajaran). ${ }^{3}$

Untuk meningkatkan mutu sekolah dan mencapai standar kompetensi harus ditunjang oleh banyak pendukung. Di antaranya adalah kepala sekolah dan guru profesional merupakan salah satu input sekolah yang memiliki tugas dan fungsi yang sangat berpengaruh pada berlangsungnya proses pendidikan. Oleh karenanya, diperlukan kepala sekolah yang profesional, sebagai pemenuhan sumber daya manusia yang baik memiliki kompetensi yang mendukung tugas dan fungsinya dalam menjalankan proses pendidikan pada satuan pendidikan.

Di samping peran kepala sekolah dalam meningkatkan mutu pendidikan ada faktor pendukung lainnya, seperti sarana dan

${ }^{3}$ Ahmad Sabri, Strategi Belajar Mengajar dan Micro Teaching (Jakarta: Quantum Teaching, 2005), hlm.34. 


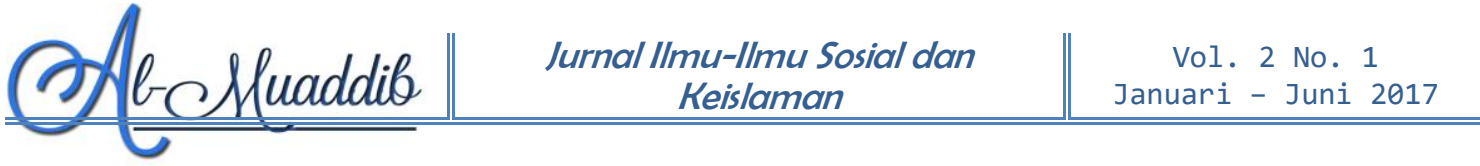

prasarana, kurikulum dan proses belajar mengajar. Kepala sekolah sebagai manajer sudah saatnya mengoptimalkan mutu pendidikan.

Menurut Dra. Nilda Rosmawati, ${ }^{4}$ kepala sekolah di SMP Muhammadiyah 29 Padangsidimpuan mengatakan bahwa manajemen mutu pendidikan di sekolah tersebut sudah terlaksana. Selain itu, peran kepala sekolah dalam meningkatkan mutu pendidikan di sekolah dapat dilihat melalui kerja sama dengan guru sehingga terwujud mutu pendidikan yang lebih baik.

Pentingnya peningkatkan mutu pendidikan tidak terlepas dari bimbingan kepala sekolah. Oleh sebab itu, kepala sekolah sudah seharusnya menyediakan sarana dan prasarana pembelajaran. Adapun penambahan program pendukung yang dilakukan di sekolah tersebut adalah mengadakan pengajian, melaksanakan muhadarah dengan menghadirkan ustadz, pelajaran praktek salat, ke tiga macam kegiatan ini dilakukan setiap hari jum'at dengan cara di selang selingi. Hapalan one day one 30 surah yang dilakukan per kelas yang dibaca setiap apel pagi. Terciptanya mutu pendidikan menjadi sangat penting untuk diwujudkan dengan sebaik-baiknya. Tulisan ini akan memuat tentang bagaimana perencanaan, pelaksanaan manajemen kepala sekolah dalam menciptakan mutu pendidikan di SMP Muhammadiyah 29 Padangsidimpuan.

\section{B. PENGERTIAN MANAJEMEN}

Manajemen berasal dari bahasa latin, yaitu dari kata manus yang berarti tangan dan agere yang berarti melakukan, kata ini digabung menjadi kata kerja yaitu manager yang artinya menangani. Dalam bahasa inggris istilah kata kerjanya disebut dengan to manage, dengan kata benda management, dan manager untuk orang yang melakukan kegiatan manajemen. Kemudian, dalam KBBI, managemen diterjemahkan dengan manajemen atau pengelolaan.

${ }^{4}$ Nilda Rosmawati, Kepala SMP Muhammadiyah 29 Padangsidimpuan, wawancara di Padangsidimpuan, tanggal 03 Oktober 2016 Pukul 10.45-11.05 WIB. 
Manajemen pada hakikatnya dapat dipahami sebagai proses kerja sama dua orang atau lebih dengan menggunakan sumber daya yang dimiliki organisasi untuk mencapai tujuan yang ditetapkan. Menurut Fatah Manajemen adalah sebagai proses merencana mengorganisasi, memimpin dan mengendalikan upaya organisasi dengan segala aspeknya agar tujuan organisasi tercapai secara efektif dan efisien. ${ }^{5}$

Manajemen pada hakikatnya membutuhkan interaksi dan sinergisitas antar komponen organisasi dengan menggerakkan sumber daya yang dimiliki, sehingga mampu mewujudkan harapan dan citacita organisasi. Sebagai suatu ilmu, manajemen memiliki objek studi, metode, strategi dan pendekatan sehingga dapat digunakan dan diterapkan dalam masyarakat.

Dengan demikian manajemen memiliki keterkaitan dengan berbagai disiplin ilmu lainnya, sehingga memungkinkan manajemen dipelajari, dianalisis, diteliti dan kemudian dikembangkan sebagai suatu ilmu terapan dalam mengelola suatu organisasi atau perusahaan. ${ }^{6}$

Menurut Stoner manajemen adalah suatu proses perencanaan, pengorganisasian, pemimpin, dan evaluasi penggunaan semua sumber daya organisasi untuk mencapai tujuan yang telah ditetapkan. Richard juga mengemukakan bahwa manajemen adalah pencapaian tujuan organisasional secara efektif dan efisien melalui perencanaan, pengelolaan, kepemimpinan, dan pengendalian sumber daya organisasional. ${ }^{7}$

5 Onisimus Amtu, Manajemen Pendidikan di Era Otonomi Daerah (Bandung: Alfabeta 2013), hlm.1-2.

Ibid, hlm.4-5.

${ }^{7}$ Yakub Vico Hisbanarto, Sistem Informasi Manajemen Pendidikan (Yogyakarta: Graha Ilmu 2014), hlm. 47-48. 


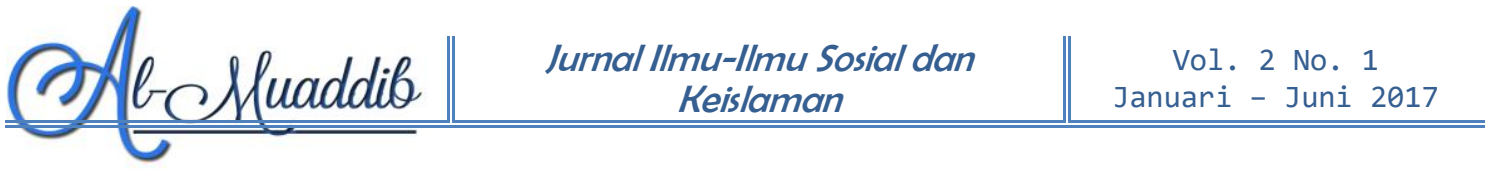

\section{Fungsi Manajemen}

Tanggung jawab pimpinan lembaga pendidikan sangat rumit dan berat karena berkaitan dengan pengelolaan sumberdaya manusia dan sumberdaya material (sarana dan prasarana) pendidikan. Oleh karena itu penguasaan terhadap manajemen sangat dibutuhkan oleh setiap pengelola pendidikan. Manajemen selalu diartikan sebagai bentuk pengelolaan terhadap suatu aktivitas organisasi. Berikut ini beberapa fungsi dari manajemen yaitu:

\section{Perencanaan (planning)}

Perencanaan adalah langkah awal merumuskan strategi, dengan mempertimbangkan kemampuan sumber daya organisasi untuk meramalkan kesuksesan di masa mendatang. Perencanaan pada dasarnya dipahami sebagai pintu masuk bagi setiap organisasi untuk menganalisis berbagai kekuatan, kelemahan, ancaman dan peluang yang dapat mempengaruhi organisasi dalam mencapai tujuan yang ditetapkan.

Menurut Usman perencanaan pada hakikatnya adalah proses pengambilan keputusan atas sejumlah alternatif (pilihan) mengenai sasaran dan cara-cara yang akan dilaksanakan di masa yang akan datang guna mencapai tujuan yang dikehendaki serta pemantauan dan penilaiannya atas hasil pelaksanaannya, yang dilakukan secara sistematis dan berkesinambungan. ${ }^{8}$

Adapun manfaat perencanaan sebagai berikut:

a. Standar pelaksaan dan pengawasan.

b. Pemilihan berbagai alternatif terbaik.

c. Penyusunan skala prioritas, baik sasaran maupun kegiatan.

d. Menghemat pemanfaatan sumber daya organisasi.

e. Membantu manajer menyesuaikan diri dengan perubahan lingkungan.

f. Alat memudahkan dalam berkoordinasi dengan pihak terkait.

g. Alat meminimalkan pekerjaan yang tidak pasti. ${ }^{9}$

8 Usman, Manajemen Pendidikan di Era Otonomi Daerah (Bandung: Alfabeta, 2013), hlm.30-32.

9 Ibid,hlm.65. 


\section{Penggerakan (Actuating)}

Fungsi penggerakan merupakan gerak pelaksanaan dari kegiatan-kegiatan perencanaan dan pengorganisasian. Penekanan dari fungsi penggerakan proyek adalah penciptaan kerja sama pada peningkatan semangat kerja keseluruhan anggota untuk tercapainya tujuan organisasi. Kegiatan pengarahan dan bimbingan sebagai perwujudan fungsi penggerakan (actuating) dalam manajemen memerlukan penciptaan dan pengembangan komunikasi secara efektif dan efisien. ${ }^{10}$

Penggerakan dalam proses pembelajaran dilakukan oleh pendidik dengan suasana yang edukatif agar siswa dapat melaksanakan tugas belajar dengan penuh antusias, dan mengoptimalkan kemampuan belajarnya dengan baik. Peran guru sangat penting dalam menggerakkan dan memotivasi para siswanya melakukan aktifitas belajar baik itu dilakukan di kelas, di laboratorium, di perpustakaan, praktek kerja lapangan, dan tempat lainnya yang memungkinkan para siswa melakukan kegiatan belajar.

Sedangkan kepala sekolah sebagai pemimpin instruksional menggerakkan semua personel dan potensi sekolah untuk mendukung sepenuhnya kegiatan pembelajaran yang dikendalikan oleh guru dalam upaya membelajarkan anak didik. ${ }^{11}$ Tugas menggerakkan dilakukan oleh pemimpin, oleh karena itu kepemimpinan kepala daerah dan kepemimpinan kepala sekolah mempunyai peran yang sangat penting menggerakkan personel melaksanakan program kerja sekolah. ${ }^{12}$

10Ibid, hlm. 56. hlm. 145 .

${ }^{11}$ Syaiful Sagala, Konsep dan Makna Pembelajaran (Bandung: Alfabeta 2013),

${ }^{12}$ Syaiful Sagala, Administrasi Pendidikan Kontemporer (Bandung: Alfabeta 2013), hlm.53. 


\section{Pengawasan (Controling)}

Pengawasan adalah perilaku individu sebagai orang-orang yang memproses lancarnya kegiatan pembelajaran dan tidak terjadi penyimpangan. Pengawasan yang dilakukan oleh pemerintah daerah kabupaten atau kota penting untuk mengukur tingkat keefektipan program layanan belajar dan manajemen satuan pendidikan. Menurut Robins pengawasan adalah proses monitor aktifitas-aktifitas untuk mengetahui apakah individu-individu dan organisasi itu sendiri memperoleh dan memanfaatkan sumbersumber secara efektif dan efisien dalam mencapai tujuan.

Pengawasan dalam lembaga-lembaga pendidikan tidak boleh dilakukan secara eksak, karena model pengawasan eksak menerapkan kontrol mesin kepada manusia. Suatu kontrol yang tidak menghargai harkat dan martabat manusia. Pengawasan yang baik adalah yang dapat memanfaatkan profesi dan karir manusia secara optimal yaitu mengikutsertakan mereka menentukan sasaran, menciptakan iklim yang mendorong pengembangan diri, dan membuat mereka responsif dengan semangat yang mendatang. 13

\section{Pengevaluasian (Evaluating)}

Pengevaluasian (evaluating) adalah proses pengawasan dan pengendalian performa sekolah untuk memastikan bahwa jalannya penyelenggaraan kegiatan di sekolah telah sesuai dengan rencana yang telah ditetapkan. Tujuan pengevaluasian adalah untuk memperoleh dasar bagi pertimbangan akhir suatu periode kerja, apa yang telah dicapai, apa yang belum dicapai dan apa yang perlu mendapat perhatian, untuk menjamin cara kerja yang efektif dan efisien, untuk memperoleh fakta tentang kesulitan, hambatan,

${ }^{13}$ Syaiful Sagala, Kemampuan Profesional Guru dan Tenaga Kependidikan (Bandung: Alfabeta 2013), hlm.71-72. 


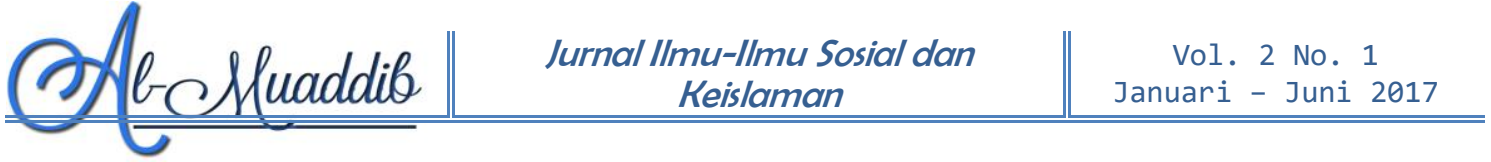

penyimpangan dilihat dari aspek tertentu misalnya program tahunan, dan kemajuan belajar.

Evaluasi sangat penting untuk meningkatkan dan menjamin kualitas sebuah program pendidikan. Evaluasi ini didasarkan pada tujuan program dan penilaian kebutuhan, dalam mengidentifikasi kekuatan dan kelemahan komponen program ini. Evaluasi program harus melibatkan semua jenis program, melibatkan orang tua dan masyarakat, pengembangan rencana pendidikan individual, stuktur lingkungan belajar, kepribadian kurikulum, ketetapan pengembangan kurikulum, dan menilai periode transisi administrasi dan perencanaan.

Evaluasi program adalah proses menentukan kualitas suatu program secara sistematis dan bagaimana program tersebut dapat ditingkatkan. ${ }^{14}$

\section{Kepala Sekolah}

Sekolah merupakan lembaga yang bersifat kompleks dan unik. Dikatakan bersifat kompleks karena sekolah sebagai organisasi di dalamnya terdapat berbagai dimensi yang satu sama lain saling berkaitan dan saling menentukan, sedangkan bersifat unik karena sekolah memiliki karakter tersendiri, dimana terjadi proses belajar mengajar, tempat terselenggaranya pembudayaan kehidupan manusia.

Kepala sekolah tersusun dari dua kata yaitu kepala dan sekolah. Kepala dapat diartikan sebagai ketua atau pemimpin dalam suatu organisasi atau sebuah lembaga. Sekolah merupakan sebuah lembaga yang merupakan tempat menerima dan memberi pelajaran. Kepala sekolah dapat didefenisikan sebagai seseorang tenaga fungsional guru yang diberi tugas untuk memimpin suatu sekolah dimana diselenggarakan proses belajar dan mengajar.

14 Op.cit, hlm. 62-64 


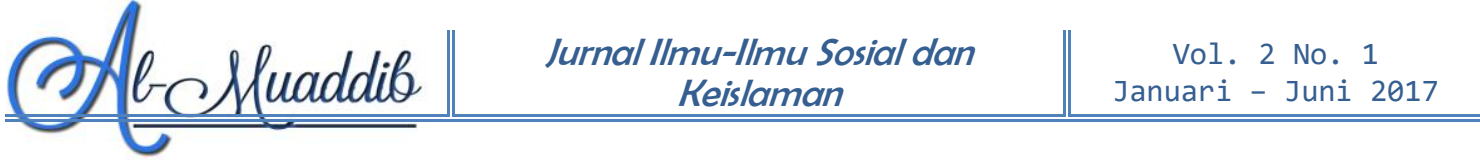

Menurut Husaini Usman menyatakan bahwa kepala sekolah sebagai manager dituntut mengorganisir seluruh sumber daya sekolah menggunakan prinsip "TEAMWORK", Yang mengandung pengertian adanya rasa kebersamaan (together), pandai meraskan (empaty), saling membantu (assist), saling penuh kedewasaan (maturity), saling mematuhi (willingness), saling teratur (organization), saling menghormati (respect), dan saling berbaik hati (kindness).

Keberhasilan pendidikan di sekolah sangat ditentukan oleh keberhasilan kepala sekolah dalam mengelola tenaga kependidikan yang tersedia di sekolah, kepala sekolah sebagai pemimpin tertinggi sangat berpengaruh dan menentukan kemajuan sekolah harus memiliki kemampuan administrasi, memiliki komitmen tinggi, dan luwes dalam melaksanakan tugasnya. ${ }^{15}$

\section{E. Mutu Pendidikan}

Mutu menurut bahasa berarti kualitas. Mutu pendidikan menekankan pengalaman dari seluruh masyarakat, bukan hanya pengalaman pribadi perorangan. ${ }^{16}$ Menurut Garvin dan Davis mutu adalah suatu kondisi dinamis yang berhubungan dengan produk, manusia atau tenaga kerja, proses dan tugas, serta lingkungan yang memenuhi atau melebihi harapan pelanggan atau konsumen.

Keunggulan mutu tidak sebatas pada areal atau wilayah bisnis dan industri, tetapi jika diterapkan di dunia pendidikan, maka akan berdampak positif baik bagi siswa, guru, maupun orang tua dan masyarakat. ${ }^{17}$ Usaha memenuhi tuntutan yang diharapkan dalam dunia mutu disebut pelayanan. Artinya mutu itu sama dengan pemberian layanan yang terus menerus sesuai dengan tuntutan dan harapan pengguna pelanggan yang membutuhkannya.

${ }^{15}$ Op.cit,hlm.37-38.

${ }^{16}$ Abuddin Nata.Persfektif Tentang Pola Hubungan Guru-Murid, Studi Pemikiran Tasawuf Al-ghazali (Jakarta: Raja Grafindo Persada,2001), hlm.83.

${ }^{17}$ Garvin dan Davis, Kepemimpinan dan supervise pendidikan (Jakarta: Bina Aksara, 1984), hlm.119-120. 


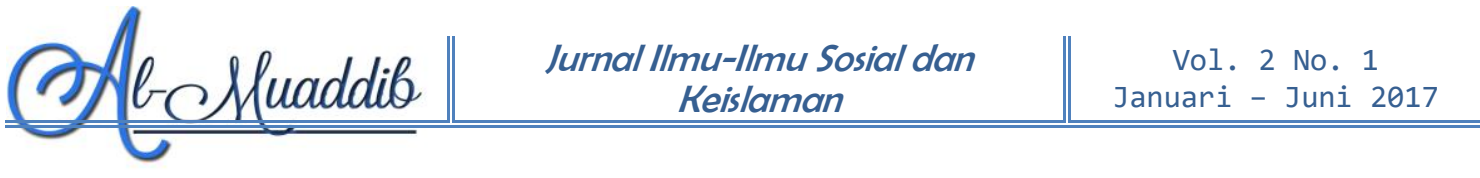

Mengingat semua pihak berkepentingan, baik pemerintah, masyarakat, dunia kerja maupun lembaga pendidikan sendiri berkepentingan dengan mutu yang baik, maka para pembuat kebijakan harus menjadikan mutu sebagai kebutuhan, sebagai prioritas utama untuk dibiayai. ${ }^{18}$

\section{F. HASIL PENELITIAN}

Sesuai dengan penjelasan yang telah ditetapkan dalam bagian pendahuluan, maka berikut ini merupakan hasil yang akan dilihat melalui manajemen (perencanaan dan pelaksanaan) kepala sekola untuk mewujudkan peningkatan terhadap mutu pendidikan di SMP Muhammadiyah 29 Padangsidimpuan.

1. Perencanaan kepala sekola dapat dilihat melalui hasil wawancara dengan Nilda Rosmawati ${ }^{19}$ yang menyatakan bahwa:

Sebagai kepala sekola saya sudah seharusnya menjadi pionir di sekolah demi mewujudkan pendidikan yang bermutu. Misalnya dalam penyampaian ide atau gagasan yang baru, maka saya kepala sekolah tidak harus serta merta menerapkan kebijakan atau ide gagasan yang baru, akan tetapi lebih dahulu disosialisasikan agar bawahan dan guru tidak terkejut atau justru terbalik dengan kebijakan itu. Hal ini merupakan salah satu perencanaan yang harus dikedepankan demi terciptanya mutu pendidikan yang berintegrasi baik dari kepala sekolah dengan guru-guru, maupun dengan tenaga kependidikan.

Lebih lanjut dijelaskan oleh Nilda Rosmawati ${ }^{20}$ yang mengatakan bahwa:

Kepala sekolah memiliki peran yang kuat dalam mengkoordinasikan, menggerakkan dan menyerasikan semua sumber daya pendidikan yang tersedia. Kepala sekolah mengadakan musyawarah dengan guru-guru, komite sekolah, tokoh masyarakat untuk menetapkan besarnya biaya yang harus ditanggung oleh siswa, kepala sekolah mengadakan musyawarah dengan guru-guru untuk pembahasan pelaksanaan safari

${ }^{18} \mathrm{H}$. Dadang Suhardan, Ekonomi dan Pembiayaan Pendidikan (Bandung: Alfabeta, 2014), hlm.68.

${ }^{19}$ Nilda Rosmawati, Kepala SMP Muhammadiyah 29 Padangsidimpuan, wawancara di Padangsidimpuan, tanggal 03 Oktober 2016.

${ }^{20}$ Nilda Rosmawati, Kepala SMP Muhammadiyah 29 Padangsidimpuan, wawancara di Padangsidimpuan, tanggal 03 Oktober 2016. 
ramadhan, kepala sekolah juga mengadakan musyawarah dengan guru-guru tentang proses pelaksanaan program semester setiap awal semester. Sekolah juga menyampaikan konsep program sekolah kepada guru-guru, siswa dan kepada orang. Program kerja Kepala Sekolah dalam jangka satu tahun yaitu mengikut sertakan guru-guru pada setiap pelatihan-pelatihan guru mata pelajaran, mengikut sertakan siswa-siswa dalam setiap perlombaan di bidang keagamaan, olah raga, seni dan olimpiade di tingkat kota maupun provinsi, meningkatkan kehadiran siswa hingga $90 \%$, meningkatkan kehadiran guru hingga $90 \%$, melaksanakan program remedial bagi siswa yang belum mencapai ketuntasan belajar, memperbanyak programprogram yang bertujuan untuk meningkatkan sikap tulus dan ikhlas serta menunjukkan ciri-ciri Islam dalam pergaulan di lingkungan sekolah juga dalam mengemban tugas dan tanggung jawab seperti pesantren kilat, safari ramadhan dan lain-lain, mengusahakan pengadaaan sarana dan prasarana yang mendukung peningkatan mutu pembelajaran seperti: ruang belajar untuk dilaksanakan proses pembelajaran, buku-buku, lapangan sekolah bisa dijadikan sebagai tempat praktek bagi materi yang membutuhkan pelaksanaan praktek, seperti shalat, wudhu, tayammum dan lain-lain.

Keberhasilan dalam meningkatkan mutu pendidikan tidak terlepas dari peran kepala sekolah dengan unsur kependidikan lainnya maka perancangan kurikulum melalui rapat dan mengundang pihakpihak yang terkait dengannya, memilih metode yang tepat untuk mencerdaskan peserta didik sehingga menjadi peserta didik bermutu, perencanaan keaktipan peserta didik (kehadiran), perencanaan tatat tertib sekolah (kedisiplinan), perencanaan dedikasi kerja, merencanakan sarana prasarana yang menunjang untuk meningkatkan mutu pendidikan. Dengan adanya perencanaan oleh kepala sekolah dengan pihak-pihak kependidikan lainnya maka peningkatan mutu pendidikan akan terwujud sesuai dengan harapan dan tujuan pendidikan itu sendiri.

2. Pelaksanaan Kepala Sekolah dalam meningkatkan mutu pendidikan

Manajemen peningkatan mutu pendidikan merupakan suatu hal yang harus direalisasikan dalam bentuk nyata melalui pelaksanaan dari apa yang telah direncanakan oleh pihak kepala sekolah dan tenaga 
kependidikan lainnya. Untuk mewujudkan mutu pendidikan yang bermutu maka pelaksaan dari perencanaan harus didasarkan kepada Standar Nasional Pendidikan (SNP) yang ditetapkan oleh pemerintah.

Dalam pelaksanan proses belajar yang sudah baik, dapat dilihat dari hasil observasi yang menggambarkan proses belajar mengajar yang tinggi, masuk jam 07.20 WIB, siswa berbaris di halaman sekolah untuk melaksanakaan apel pagi, dalam pelaksanaan ini guru telah menentukan jadwal pelaksana apel pagi setiap harinya. Jam 07.30 WIB siswa sudah mulai belajar di kelas.

Untuk memperkuat pernyataan di atas maka peneliti sudah melakukan wawancara dengan siswa ${ }^{21}$ SMP Muhammadiyah 29 Padangsidimpuan yang menjelaskan bahwa:

Kami masuk di sekolah ini pada jam 07.20, pulang jam 13.30 WIB".

Kemudian dalam wawancara selanjutnya maka kepala sekolah ${ }^{22}$ juga memberikan komentarnya bahwa:

Untuk menciptakan mutu pendidikan yang baik, maka guru harus melaksanakan tugasnya dengan baik sesuai dengan tanggung jawabnya. Dalam menjalankan tugasnya, guru harus menjunjung tinggi kode etik guru. Guru kita sudah memberikan layanan yang baik terutama dalam kegiatan belajar mengajar di kelas, sehingga orang tua maupun masyarakat benar-benar puas dengan kinerja guru. Menurut keterangan kepala sekolah di ruang kerjanya, intinya adalah: kami mengetahui ini dari mayarakat, khususnya orang tua yang memiliki anaknya sebagai siswa di sekolah ini, dan melalui komite sekolah yang telah banyak memberikan masukan dan saran yang berguna untuk meningkatkan kemajuan sekolah.

Selanjutnya, kepala sekolah juga diberikan kesempatan untuk melakukan improvisasi dan berkreasi dalam meningkatkan mutu pendidikan. Guna mengetahui bagaimana keterlibatan guru dalam

\footnotetext{
${ }^{21}$ Rizki Mulyadi, Siswa Kelas IX SMP Muhammadiyah 29 Padangsidimpuan, Wawancara di halaman sekolah, tanggal 24 Oktober 2016

${ }^{22}$ Nilda Rosmawati, Kepala SMP Muhammadiyah 29 Padangsidimpuan, wawancara di Padangsidimpuan, tanggal 03 Oktober 2016.
} 
berimvrovisasi dan berkreasi sehingga tercipta pendidikan yang bermutu maka kepala sekolah ${ }^{23}$ juga menjalskan bahwa:

Guru diberikan kebebasan dalam memilih strategi, metode, dan teknik pembelajaran dan pengajaran yang efektif sesuai dengan karakteristik mata pelajaran, karakterstik siswa, karakteristik guru dan kondisi yang tersedia di sekolah.

Menurut keterangan salah seorang siswa menggambarkan bahwa:

Guru yang mengajar di kelas tidak menggunakan satu metode mengajar. Guru menggunakan metode yang bervariasi seperti ceramah, diskusi, praktek dan lain-lain.

Hasil wawancara dengan guru ${ }^{24}$ bidang studi PAI menjelaskan bahwa:

Di SMP Muhammadiyah 29 Padangsidimpuan diterapkan belajar tuntas, siswa belajar sampai tuntas baru dilanjutkan pelajaran selanjutnya. Guru juga melakukan remedial, jika ada siswa yang belum tuntas dalam pembelajaran. ${ }^{25}$

Selanjutnya untuk melihat pelaksanaan sebagai sebuah manajemen oleh kepala sekolah, maka peneliti juga sudah melakukan wawancara dengan seorang siswa ${ }^{26}$ pada waktu istirahat berlangsung yang menyatakan bahwa:

Guru mengulang pelajaran jika tidak mengerti apa yang sudah diterangkan. Guru juga menyarankan agar membaca buku di perpustakaan untuk membantu memahami pelajaran yang sudah diterangkan. Buku-buku paket di perpustakaan lengkap sesuai dengan jumlah mata pelajaran yang ada meskipun jumlahnya tidak sesuai dengan jumlah siswa. Terkadang satu buku digunakan untuk dua orang siswa.

Guna mengoptimalkan pelaksanaan manajemen sekolah yang efektif dan efisien maka diperlukan sebuah tanggungjawab penuh

${ }^{23}$ Nilda Rosmawati, Kepala SMP Muhammadiyah 29 Padangsidimpuan, wawancara di Padangsidimpuan, tanggal 03 Oktober 2016.

${ }^{24}$ Isnan Riadi Lubis, Guru Pendidikan Agama Islam SMP Muhammadiyah 29 Padangsidimpun, wawancara, 24 Oktober 2016

${ }^{26}$ Firza Khairani, Siswa Kelas IX SMP Muhammadiyah 29 Padangsiidmpuan, wawancara di halaman sekolah, tanggal 24 oktober 2016. 


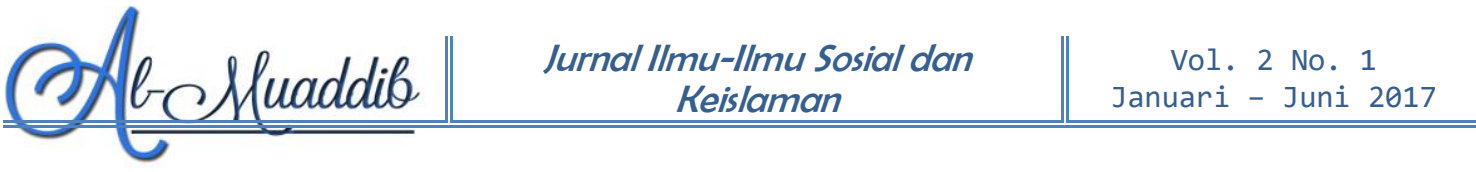

dengan berbagai pihak termasuk orang tua, pihak sekolah dan masyarakat, pemerintah pusat dan daerah, maka kepala sekolah ${ }^{27}$ juga sudah menjelaskan bahwa:

Tercapinya kedisiplinan mulai dari disiplin waktu sampai disiplin kerja adalah sesuatu yang sangat fundamental. Tanggung jawab ini merupakan perwujudan dari tanggung jawab moral yang harus dibudidayakan. Selain tanggung jawab moral, kepala sekolah juga memberikan kepada para guru dan tata usaha tentang tanggung jawab akademik, diantaranya:

a. Setiap guru mata pelajaran harus menguasai materi yang akan diajarkan sesuai dengan bidang masing-masing. Guru juga harus menguasai metode, teknik dan cara mengajar yang baik, sehingga siswa dapat dengan mudah menerima informasi yang disampaiakn.

b. Memberikan penilaian yang sebenarnya kepada siswa sesuai dengan tingkat kecerdasannya, baik kecerdasan otaknya maupun kecerdasan emosionalnya.

c. Memberikan laporan secara berkala kepada wali kelas untuk mengetahui perkembangan siswa dalam menerima materi pelajaran sesuai bidang studi masing-masing.

1. Selain itu, kepala sekolah28 juga menyampaikan bahwa:

Akuntabilitas merupakan pertanggungjawaban yang harus dilakukan sekolah terhadap keberhasilan program yang telah dilakukan. Ini berbentuk laporan prestasi siswa dan dilaporkan kepada pemerintah, orangtua siswa, dan masyarakat. Pengawas sekolah langsung memantau proses evaluasi belajar dan penilaian hasil ujian akhir siswa, setiap akhir semester raport dibagikan kepada siswa.

Menurut keterangan guru 29 bidang studi IPS bahwa:

Kepala sekolah memberikan pengarahan kepada semua guru dan staf tata usaha dalam setiap kesempatan yang menyangkut pelaksanaan tugas dan taggung jawab masing-masing. Ini berarti guru-guru diarahkan untuk menjalankan semua program yang sudah di susun berdasarkan kurikulum yang berlaku untuk mencapai tujuan yang telah dirumuskan.

${ }^{27}$ Nilda Rosmawati, Kepala SMP Muhammadiyah 29 Padangsidimpuan, wawancara di Padangsidimpuan, tanggal 03 Oktober 2016.

${ }^{28}$ Nilda Rosmawati, Kepala SMP Muhammadiyah 29 Padangsidimpuan, wawancara di Padangsidimpuan, tanggal 03 Oktober 2016.

${ }^{29}$ Efni Ra Harahap, Guru Ilmu Pengetahuan Sosial di SMP Muhammadiyah 29 Padangsidimpuan, Wawancara di Padangsidimpuan, tanggal 29 Oktober 2016. 
Perwujudan keterbukaan dan kepercayaan dalam pengelolaan pendidikan, sesuai dengan otoritas masing-masing Yang dapat membangun kesatuan dan persatuan bangsa. Keterbukaan atau transparansi dalam mengelola sekolah merupakan karakteristik sekolah yang menerapkan manajemen.

Hasil wawancara dengan Wakil Kepala Sekolah I30 di ruang guru menggambarkan bahwa:

Kepala sekolah, guru, komite sekolah mengadakan musyawarah membahas tentang besarnya SPP dan uang pembangunan. Segala bentuk kebijakan diputuskan bersama-sama antara kepala sekolah, guru, dan komite sekolah.

Hasil wawancara tersebut di atas menggambarkan bahwa setiap ada permasalahan di sekolah selalu diputuskan bersama-sama, sehingga permasalahan yang ada dengan mudah diatasi. Kemudian, Penyelesaian masalah pendidikan sesuai dengan karakteristik wilayah yang bersangkutan. Sebagai seorang kepala sekolah yang berfungsi sebagai pemimpin, harus mau dan siap mendengar saran dan ide-ide dari guru, utamanya dalam rangka peningkatan kualitas atau kemampuan guru. Bukan hanya mendengar, akan tetapi lebih pada melaksanakan, jika ide atau saran itu menunjang peningkatan profesionalisme guru.

Wawancara selanjutnya dengan Bapak Isnan Riadi Lubis ${ }^{31}$ menjelaskan bahwa:

Ibu kepala sekolah ini agak keras, tetapi jika keputusan yang diambil tidak pas, maka diadakan rapat untuk membicarakan secara baik dan biasanya ibu juga menerima dan mau mengklarifikasi, demikian sebaliknya.

${ }^{30}$ Eva Nilasari, WK I Kurikulum SMP Muhammadiyah 29 Padangsidimpuan, wawancara di Padangsidimpuan, tanggal 29 Oktober 2016.

${ }^{31}$ Isnan Riadi Lubis, Guru Pendidikan Agama Islam SMP Muhammadiyah 29 Padangsidimpun, wawancara di Padangsidimpuan, tanggal 24 Oktober 2016 


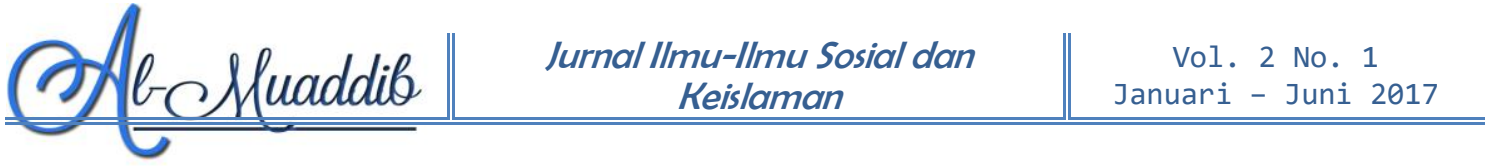

\section{G. PENUTUP}

Manajemen kepala sekolah dalam meningkatkan mutu pendidikan di SMP Muhammadiyah 29 Padangsidimpuan sudah terlaksana dengan baik. Dalam perencanaan kepala sekolah melakukan rapat untuk merencanakan program tahunan hasil dari rapat akan disosialisasikan kepada guru, siswa, orang tua dan komite sekolah. Program kerja Kepala Sekolah dalam jangka satu tahun yaitu mengikut sertakan guru-guru pada setiap pelatihan-pelatihan guru mata pelajaran, mengikut sertakan siswa-siswa dalam setiap perlombaan di bidang keagamaan, olah raga, seni dan olimpiade di tingkat kota maupun provinsi, meningkatkan kehadiran siswa hingga $90 \%$, meningkatkan kehadiran guru hingga 90\%, mengusahakan pengadaaan sarana dan prasarana yang mendukung peningkatan mutu pembelajaran seperti: ruang belajar untuk dilaksanakan proses pembelajaran, buku-buku, lapangan sekolah bisa dijadikan sebagai tempat praktek bagi materi yang membutuhkan pelaksanaan praktek, seperti shalat, wudhu, tayammum dan lain-lain.

Dalam pelaksanaan kepala sekolah dapat dibuktikan dengan kegiatan-kegiatan khusus pembelajaran seperti: pengajian, muhadaroh dengan menghadirkan ustadz, praktek shalat, hapalan one day one ayat yang dilakukan secara bergiliran dan di baca setiap apel pagi. Kemudian dalam proses pembelajaran kepala sekolah mensarankan agar guru menggunakan metode yang bervariasi, disiplin terhadap jadwal masuk kelas, adanya pertanggungjawaban kerja, bermusyawarah dalam memutuskan suatu permasalahan, keterbukaan dalam hal penetapan biaya SPP dan uang pembangunan. 


\section{DAFTAR PUSTAKA}

Amtu Onisimus, Manajemen Pendidikan di Era Otonomi Daerah, Bandung: Alfabeta, 2013

Davis dan Garvin, Kepemimpinandan Supervisi Pendidikan, Jakarta: BinaAksara, 1984

Nata Abudin, Perspektif Tentang Pola Hubungan Guru-Murid, Jakarta: Raja Grafindo Persada, 2001

Sabri Ahmad, Strategi Belajar Mengajar Dan Micro Teaching, Jakarta: Quantum Teaching, 2005

Sagala syaiful, Administrasi Pendidikan Kontemporer, Bandung: Alfabeta, 2008 , Manajemen Statistik Dalam Peningkatan Mutu Pendidikan, Bandung: Alfabeta, 2011

, Kemampuan Profesional Guru Dan Tenaga Kependidikan, Bandung: Alfabeta, 2013 2013

Konsep dan Makna Pembelajaran, Bandung: Alfabeta, Administrasi Pendidikan Kontemporer, Bandung: Alfabeta, 2013

Suhardan Dadang, Ekonomi Dan Pembiayaan Pendidikan, Bandung: Alfabeta, 2014

Usman, Manajemen Pendidikan Di Era Otonomi Daerah, Bandung: Alfabeta, 2013

Usman Husain, Manajemen, Teori, Praktek, dan Riset Pendidikan, Edisi 3, Jakarta: Bumi Aksara, 2009

Vico, Yakub Hisbanarto, Sistem Informasi Manajemen Pendidikan, Yogyakarta: Graha Ilmu, 2014 